\title{
Theoretical analysis of business risks
}

\author{
Baymirzayev Dilmurod Nematovich ${ }^{\mathbf{1}}$ \\ ${ }^{1}$ PhD student of Namangan State University, Namangan, Republic of Uzbekistan
}

Email: baymirzayevd@@namdu.uz

\begin{abstract}
Internal risks associated with economic activity are directly related to the processes of production, reproduction, treatment and management. Production risks, in turn, are subdivided into separate types of farm activities: basic, additional and service processes. Entrepreneurs face different set of risks that differ from each other by the way and place of origin, the combination of external and internal factors influencing the level of risks, methods of analysis and description. All risks are interconnected, and to some extent, they affect the business. At the same time, a change in a particular risk will affect many other types of risks.
\end{abstract}

Keywords: activity, business, entrepreneurial activity, risk, risks, entrepreneurial risk.

\section{INTRODUCTION}

Agriculture is one of the high-risk sectors of the agro-industrial complex, which operates under the influence of internal and external risks. The results of the activities of agricultural producers are directly related not only to the amount and quality of labor, the level of technology and technology used, but also to the objective high risk conditions for agricultural production.

Risk research remains one of the most important modern areas of economic research. Risk studies play an important role in predicting economic development and making optimal decisions. Achieving sustainable agricultural production requires research in industry risks. It is necessary to establish a system of organizational and economic measures to reduce the negative impact of risk factors on the production and financial results of agricultural enterprises.

At present, the privatization process in the agricultural sector is completed and thousands of private business entities, such as farms and dehkan farms, have been created. Business and entrepreneurial activity are inevitably associated with the elements of risk.

In modern society, the risks are obvious. The Company is exposed to various risks in all areas of its activities, including political, economic, environmental, psychological, legal, medical and other types of activities. To any economic activity there are risks of one or another level. In this sense, it is impossible to imagine business without risk. The increase in risk is inherently an obstacle to the freedom of entrepreneurial activity, and the risk is the specific cost of doing business. To survive in market conditions, technical and technological modernization and stamina require active action, which in turn leads to increased risks in entrepreneurship. The entrepreneur takes the risk of making a product (JB) and takes risks.

\section{ANALYSIS AND RESULTS}

In a market economy, any economic activity is primarily a profit-making activity, and the main purpose of farms is to make a profit. Therefore, profitability in agribusiness is closely linked to different risks. Therefore, the task of the farms is to mitigate the imbalance between the risks and the profits, to achieve its optimum level.

Therefore, when it comes to risks, it is best to focus on the nature, nature, causes, and socioeconomic consequences of these risks.

Risks are a comprehensive economic concept. It can include various levels of risks that arise in the process of setting up, running a business, making a profit or otherwise. 
Risk has followed him at all stages of society's development. Historical dangers initially had a negative impact on people as a consequence of the hazardous processes during natural disasters, but with the emergence and development of commodity-money relations, it began to act as an economic category.

Historically, at first, risks were theoretically investigated in two areas of human activity: financial and security.

The notion of risk as an economic category has been studied by a number of foreign and local economists, with different definitions of its economic nature.

The notion of risk is interpreted as 'risk' in foreign literature, in particular English and Russian. Some experts believe that the term "risk" comes from the Greek word "ridsicon", "ridsa" - vertical rock, rock - other scientists say that its root meaning is Spanish (risco - steep rock), Italian (risicare - rocky left). insist, risico - danger, danger, destruction), originate from French (risque - dangerous, doubtful) words, or derive from Latin (rescum - unpredictable, threatening or destructive).

In Webster's Encyclopedic Unabridged Dictionary, the word "risk" refers to the possibility of damage or loss, a risk, that is, an accident, while the word "risk" refers to luck or the hope of success. action.

In the explanatory dictionary of the Uzbek language, the word "danger" is expressed in the sense of danger, anxiety, panic, anxiety and is interpreted as "a condition that can lead to disaster or disaster."

Although various linguists comment on the meaning of the word almost unambiguously, it should be noted that there are some differences in their views. Specifically, Dahl describes the word "risk" as being risky, doing something dangerous, and risking the concept of "risk", not doing something wrong, being brave, determined, and risking certain risks.

S.Ushakov understands the word "risk" as a threat or possibility of causing any harm. However, linguistic definition of the concept of risk in modern conditions does not adequately reflect the essence and significance of enterprise management as an important category.

Under the conditions of a market economy, the concept of risk in business activities has expanded and has become much more meaningful, and in some cases inconsistent, even contradictory. In particular, VKherkasov notes that in economic literature there are more than 40 types of classification of risks and more than 220 manifestations of risks ${ }^{1}$.

In the economic literature, it is also widely accepted that risk is a risk or a failure. In modern economic dictionaries, the risk is the probability of occurrence of negative consequences as a result of certain decisions or actions; you can see many comments about the potential for loss or loss of profits, as well as the lack of profit and loss of profit ${ }^{2}$.

The category of risk is broad in the sense that it is likely to cause unintended consequences, losses and negative consequences; in the short term it is "a condition that may result in loss of assets or investments as a result of the activities of individuals or firms in uncertain economic conditions" ${ }^{3}$. As a result, an enterprise loses some of its resources, fails to generate revenue, or incurs additional costs.

In general, in almost all definitions of the term risk, the concepts of its characteristic, ie the possibility of risk and failure, are combined.

Risk is a model of human behavior that recognizes the possibility of potential threats.

In economic theory, through this notion, economic coincidence is defined as a reality with negative consequences.

It is well known that the entrepreneur is one of the market entities engaged in high economic risks. The ultimate goal of a business is to maximize profits by avoiding various risks, but by anticipating it and choosing the best way to minimize or prevent $\mathrm{it}^{4}$.

Entrepreneurs face different set of risks that differ from each other by the way and place of origin, the combination of external and internal factors influencing the level of risks, methods of analysis and description.

\footnotetext{
${ }^{1}$ V.V. Cherkasov. Risk problems in management. M .: "Refl-book", K .: "Wackler", 2002.320 p..

${ }^{2}$ Great economic dictionary. / Ed. A.N. Azriliyana. - 6th ed. add. and reslave. -M .: Institute of the New Economy, $2004 .-$ p.956.

${ }^{3}$ Pass Christopher. Dictionary of Economics Collins / C. Pass, B. Lowes, L. Davis - St. Petersburg: School of Economics, 2004 , p. 489.

${ }^{4}$ Tashmurodova B., Khamdamov O. Financial Management. Tutorial. Ministry of Higher and Secondary Special Education of the Republic of Uzbekistan, TMI, - T .: "Economy-Finance" 2012. 62 p.
} 
All risks are interconnected, and to some extent, they affect the business. At the same time, a change in a particular risk will affect many other types of risks.

In the context of modern production activities, special attention is paid to risk management as an integral part of the effective management of the enterprise by agricultural entities. Proper organization of risk management functions in the overall management system of the enterprise will provide an opportunity to protect the enterprise from the negative impact of external and internal factors and, in general, to increase its efficiency.

Depending on the main industry based on the organization of production in multi-sector farms (ie concentrating within a single farm on the basis of combining the following technological sequences of production, vertical coverage of the process from raw material to sale). or a horizontal way of producing products and services similar to those of the main industry, but not technologically related. the creation of a reach, engage in entrepreneurial activity in other sectors not prohibited by law.

Figure 1.

\section{Model of a multi-disciplinary farm ${ }^{5}$}

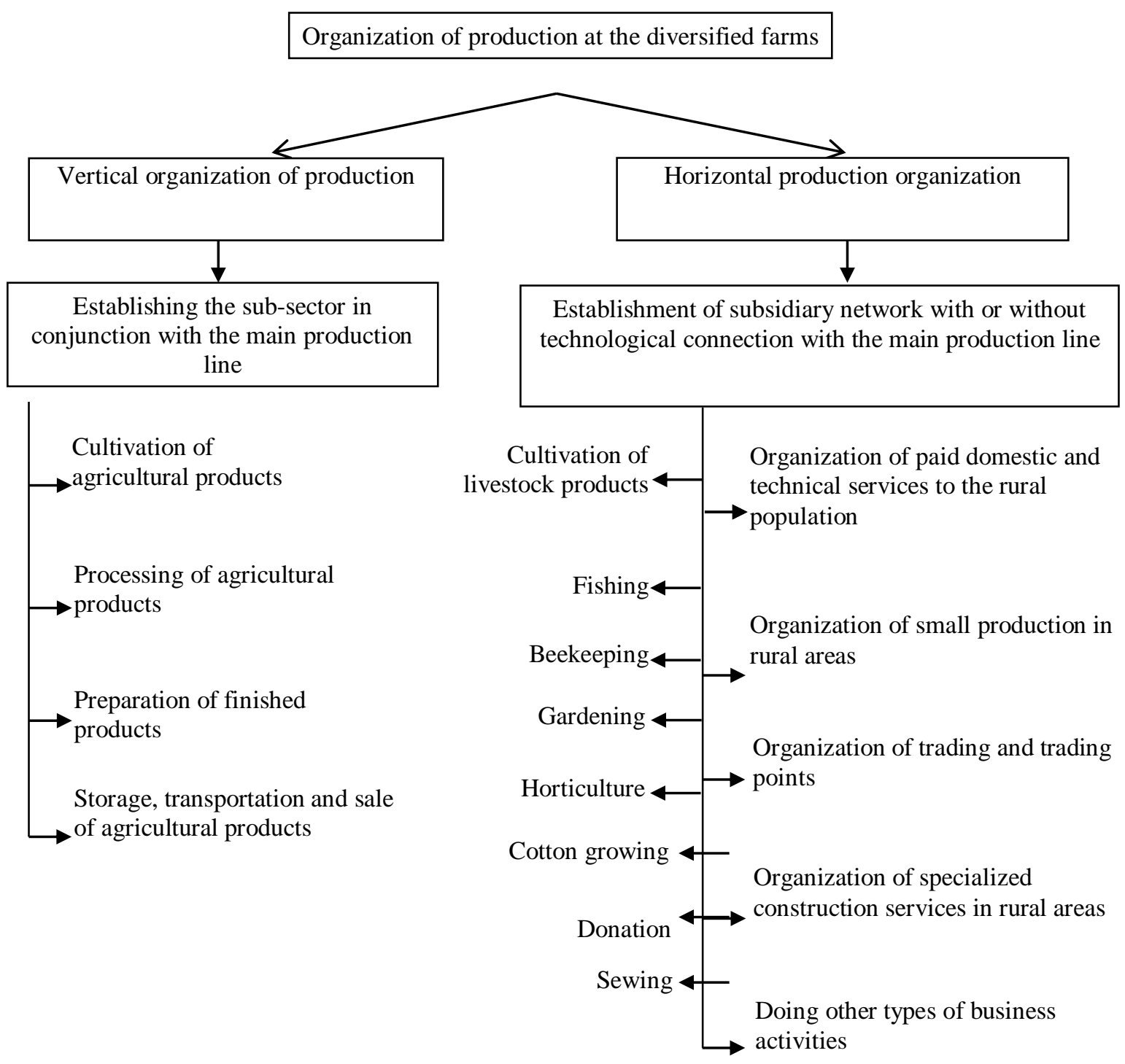

A diversified farm is a farm that has established production (tangible and intangible) in areas other than the main area of specialization specified in the long-term lease of land plots ${ }^{6}$.

\footnotetext{
${ }^{5}$ Developed by the author.

${ }^{6}$ N. Khushmatov, H. Kalimbetov. "Creating diversified farms is an important area for agricultural development". Collection of theses of scientific-practical conference. KarSU. Nukus: 2015. -38-39.
} 
The effective functioning of agricultural commodity producers implies diversification of production, ie the creation of finished agricultural products or provision of different types of paid services in rural areas through the creation of additional production with the basic production of farms. .

In practice there are two types of diversification:

1) production diversification; 2) product diversification.

Diversification of production means the simultaneous development of many unrelated production types, expansion of the range of manufactured products. For example, the establishment of farms along with agricultural production includes services such as services, commerce, construction, and processing.

The main goal of diversification of production on farms is to increase profit and reduce risks by establishing several industries. Diversified farms are economically sustainable and have a lower risk of changes due to conjunctional, structural and cyclical changes.

The development of diversified farms is one of the key to sustainable and effective agricultural development in the long run. The strat of action envisages the following tasks in order to create favorable conditions for the development of diversified farms, ensuring their economic efficiency and financial sustainability:

Creation of normative and legal basis for the activity of diversified farms, support to them by the state, including preferential lending;

Development of cooperation of farms in the production, processing, storage and sale of agricultural products, the establishment of small businesses and their units in rural areas;

Improvement of the agricultural financing system and settlements with agricultural producers.

Farmers and dehkan farms are the leading force in the production of various quality products in the agricultural sector. Necessary measures have been taken to create diversified farms, to create the necessary conditions for them, to protect the rights and legitimate interests of farmers and dehkans.

As a result of the reforms, more than $99 \%$ of agricultural production has been achieved on farms and dehkan farms and household plots ${ }^{7}$.

Achievement of sustainable development of farms in agrarian sector, introduction of market mechanisms in the system, further development of diversified farms, sustainable growth of agricultural production and effective land use. and their classification is important. Risk management in agricultural production, in many ways, necessitates the development and implementation of comprehensive methods.

Sustainable agricultural development depends on adaptation to the changing environment, prevention or mitigation of various risks and risks. Agriculture has the largest impact on the risk factors compared to other sectors of the economy. There are different classifications of risks ${ }^{8}$. Of course, they are classified according to their origin and identify four major areas of risk.

Economic risks are risks directly related to economic activity and regulated by market conditions. Eliminating or mitigating these risks requires further improvement and further development of economic cooperation between enterprises and industries.

Risk categorization refers to systematizing them according to certain criteria and criteria, and enables the integration of risks into more general concepts.

The most important components in risk classification are:

Risk occurrence;

the main factors of risk occurrence;

the aspect of their accounting;

The nature of the consequences of the risks;

Risks and others.

Risks in the activities of agricultural enterprises cause disturbance of the normal duration of agricultural production as a result of the impact of natural and climatic and anthropogenic factors and increase the likelihood of damage or profitability of economic entities, ie the level of danger.

\footnotetext{
${ }^{7}$ Decree of the President of the Republic of Uzbekistan dated October 9, 2017 № PF-5199 "On measures to protect the rights and legitimate interests of farmers, dehkan farms and homeowners, radically improve the system of efficient use of agricultural land."

${ }^{8}$ Kondratyeva, M. N. Enterprise Economics: textbook, manual for students of higher educational institutions. Ulyanovsk: UlSTU, 2008 .-- 241 p.
} 
Classification of risks in the activities of agricultural enterprises is a very difficult task. To date, their overall classification has not yet been developed. This is because there are many different types of risks manifested in practice, and the same risk can be represented by different terms.

Financial risks associated with the loss of solvency in manufacturing (technical and technological), investment and management activities, and internal turnover are internal risks that are controlled by economic entities.

Internal risks associated with economic activity are directly related to the processes of production, reproduction, treatment and management. Production risks, in turn, are subdivided into separate types of farm activities: basic, additional and service processes.

Risk management on farms is divided into several stages ${ }^{9}$ :

1. Determining the risks to the activities of farms;

2. Assessment of the impact of risks on economic activities;

3. Developing measures to neutralize high economic risks;

4. Monitoring the implementation of risk management measures;

5. Analysis of the effectiveness of the measures taken

Table 2.

Formation of information on risk identification

\begin{tabular}{|l|l|}
\hline \multicolumn{1}{|c|}{ Risks } & \multicolumn{1}{c|}{ Information sources } \\
\hline External & $\begin{array}{l}\text { Media } \\
\text { Legislative acts (laws, decisions, decrees, etc.) } \\
\text { Consulting and analytical services agencies }\end{array}$ \\
\hline Inner & $\begin{array}{l}\text { Farm business records (financial and accounting documents, etc.) } \\
\text { Expert advice (employed by the farm or outside) } \\
\text { Technical tools, archives, statistics }\end{array}$ \\
\hline
\end{tabular}

One of the traditional methods of risk identification is SWOT analysis. This analysis will identify external and internal risks that threaten the operation of the farm. At the same time, it will be possible to compare the strengths and weaknesses of a diversified farm (Table 3).

Table 3

An overall SWOT analysis of a multi-disciplinary farm ${ }^{10}$

\begin{tabular}{|c|c|c|}
\hline & strengths & weaknesses \\
\hline & "O" — OPPORTUNITIES & "T" — THREATS \\
\hline $\begin{array}{c}\text { External } \\
\text { risks }\end{array}$ & $\begin{array}{l}\text { 1. New types of products and services } \\
\text { 2. New technologies and techniques } \\
\text { 3. Access to a wide range of consumer } \\
\text { markets } \\
\text { 4. Operation on multiple networks } \\
\text { 5. Identify your target customers } \\
\text { 6. Providing additional services } \\
\text { 7. Production of finished agricultural } \\
\text { products } \\
\text { 8. Collaboration with other businesses } \\
\text { 9. Opportunity to advertise products } \\
\text { 10. Employment of farm workers and } \\
\text { employees all year round } \\
\text { 11. Good public relations } \\
\text { 12. Continuous operation throughout the } \\
\text { year } \\
\text { 13. State support }\end{array}$ & $\begin{array}{l}\text { 1. Substitute products } \\
\text { 2. Competitors in the industry or industry } \\
\text { 3. Poor supply } \\
\text { 4. Decrease in product life } \\
\text { 5. Change in demand / increase in consumer } \\
\text { taste } \\
\text { 6. Legal regulation of activities: } \\
\text { a. New customs procedures } \\
\text { b. New legislative procedures } \\
\text { 7. Competitors' judgment } \\
\text { 8. Pricing activities } \\
\text { a. Strategic programs } \\
\quad \text { b. Additional services } \\
\text { 9. Seasonal fall in prices for agricultural } \\
\text { products } \\
\text { 10. Economic crises in the industry or } \\
\text { industry }\end{array}$ \\
\hline
\end{tabular}

\footnotetext{
${ }^{9}$ Management. Journal. No. 3 (43) - 2017. Page 8.

${ }^{10}$ Developed by the author.
} 


\begin{tabular}{|c|c|c|}
\hline & "S" - STRENGTH & "W" - WEAKNESS \\
\hline $\begin{array}{l}\text { Internally } \\
\text { risks }\end{array}$ & $\begin{array}{l}\text { 1. Have great experience } \\
\text { 2. High quality products } \\
\text { 3. Achievement of popular farm level in the } \\
\text { region } \\
\text { 4. Achieve high sales volume } \\
\text { 5. Become a leading farm in a network or in } \\
\text { a rural area } \\
\text { 6. Use of innovative technologies in } \\
\text { business activities, patents } \\
\text { 7. Reduction of prime cost } \\
\text { 8. Satisfaction of consumer demand } \\
\text { 9. Well-developed entrepreneurial activity } \\
\text { 10. Strong corporate team } \\
\text { 11. Means of quality production } \\
\text { 12. Wide range of products } \\
\text { 13. Qualified workers }\end{array}$ & \begin{tabular}{|l} 
1. Lack of working capital \\
2. Low popularity of the product \\
3. Poor farm reputation \\
area \\
5. Poor marketing policy \\
6. Lack of corporate culture \\
7. Lack of clear strategies \\
8. Internal political problems of the farm \\
9. Specialization in narrow agricultural \\
production \\
10. Lack of staff and staff skills \\
11. Low motivation of workers and \\
employees \\
12. Availability of an unidentified trademark \\
on the market \\
13. Lack of post-sale services \\
14. Lack of additional services
\end{tabular} \\
\hline
\end{tabular}

On the basis of such analysis it is possible to determine whether there is a need to develop some measures to eliminate certain types of farm risks or reduce economic losses and damages. This is because excessive insurance against production risks can lead to negative consequences and significant costs.

\section{CONCLUSION/RECOMMENDATIONS}

Thus, risk is a financial and economic category, which is a set of factors that cause enterprises to deviate from their stated goals, profit or loss in the planned amounts, profit or loss.

Therefore, the strategic policy of the enterprise should focus on risk management. Risk managers at the enterprise must have excellent skills, excellence in theoretical knowledge, and profound practical skills. The fact that the enterprises operating in our country, based on the best practices of foreign countries in this field, can be put into practice will have positive results in the future.

\section{REFERENCES}

1. V.V. Cherkasov. Risk problems in management. M .: "Refl-book", K .: "Wackler", 2002.320 p..

2. Great economic dictionary. / Ed. A.N. Azriliyana. - 6th ed. add. and reslave. $-\mathrm{M}$.: Institute of the New Economy, 2004. - p.956.

3. Pass Christopher. Dictionary of Economics Collins / C. Pass, B. Lowes, L. Davis - St. Petersburg: School of Economics, 2004, p. 489.

4. Tashmurodova B., Khamdamov O. Financial Management. Tutorial. Ministry of Higher and Secondary Special Education of the Republic of Uzbekistan, TMI, - T .: "Economy-Finance" 2012. $62 \mathrm{p}$.

5. N. Khushmatov, H. Kalimbetov. "Creating diversified farms is an important area for agricultural development". Collection of theses of scientific-practical conference. KarSU. Nukus: 2015. -3839.

6. Decree of the President of the Republic of Uzbekistan dated October 9, 2017 № PF-5199 "On measures to protect the rights and legitimate interests of farmers, dehkan farms and homeowners, radically improve the system of efficient use of agricultural land.

7. Kondratyeva, M. N. Enterprise Economics: textbook, manual for students of higher educational institutions. - Ulyanovsk: UISTU, 2008 --- 241 p.

8. Management. Journal. No. 3 (43) - 2017. Page 8.

9. Resolution of the Cabinet of Ministers of the Republic of Uzbekistan dated November 29, 2018 № 972 "On approval of the Regulation on the procedure for forming and maintaining the register of multi-sectoral farms". 
10. Decree of the President of the Republic of Uzbekistan dated October 9, 2017 "On measures to protect the rights and lawful interests of farmers, dehkan farms and household owners, radical improvement of the efficient use of agricultural land". http://lex.uz/docs/3371644.

11. Decree of the President of the Republic of Uzbekistan dated October 9, 2017 № PF-5199 "On measures to protect the rights and legitimate interests of farmers, dehkan farms and homeowners, radically improve the system of efficient use of agricultural land."

12. Mirziyoev Sh.M. Let's build a free and prosperous, democratic Uzbekistan with our brave and noble people: Speech at the joint session of the Chambers of the Oliy Majlis on the inauguration ceremony of the President of the Republic of Uzbekistan. // The Word of the People, December 15,2016

13. Abduganiev, AA Abduganiev - Economics of agriculture - (textbook) - T .: TSIU, 2004 - pp. 8081 .

14. Abdullaev YO, Koralieva T., Toshmurodov Sh., Abdullaeva S. Banking. Textbook - T. ECONOMY, 2009. Page 414.

15. Abdullaeva Sh. Bank risks and their lending. - T .: "Finance", 2002.

16. Algin A.P. Risk and ego role in obshchestvennoy face. M., 1989., p. 87.

17. Bokusheva R., Heidelbach O. Actual aspects of insurance in selskom owners. Discussion Paper. No 57. 2004.

18. Boltaboev M., Kasymova M, Ergashkhodjaeva Sh., Goyibnazarov B., Samadov A., Otajanov Sh. Small business and private entrepreneurship. Textbook. T.-Economics, 2011. pp. 12-13.

19. Great economic dictionary. / Ed. A.N.Azrilliyana. - 6th ed. add. and reslave. $-\mathrm{M}$.: Institute of the New Economy, 2004. - p.956.

20. V.V. Cherkasov. Risk problems in management. M .: "Refl-book", K .: "Wackler", 2002.320 p ..

21. Grabovy P.G. Risks in modern business / P.G. Grabovy, S.N. Petrova, S.I. Poltatsev et al. - M.: Alans, 1994. - 200 p.

22. Dahl V. Explanatory Dictionary of the Living Great Russian Language. M., 1980.V.4., P. 9.

23. Zadorozhnaya M.V., Reshetnikova N.V. Foreign experience in managing risk in the agri-food sector: the role of the state. Regional Agro Systems: Economics and Sociology: Yearbook [Electronic Resource]. - Saratov: IAGPRAN. - 2017. - No. 1.

24. Kondratyeva, M. N. Enterprise Economics: textbook, manual for students of higher educational institutions. - Ulyanovsk: UISTU, 2008 .-- 241 p.

25. International experience in public-private partnerships and government support in agricultural insurance. http://agroinsurance.com/en/29980/

26. Management. Journal. No. 3 (43) - 2017. Page 8.

27. Minakov I.A. Agricultural Economics. Textbook. - M .: INFRA-M, 2017.

28. N. Khushmatov, H. Kalimbetov. "Creating diversified farms is an important area for agricultural development”. Collection of theses of scientific-practical conference. KarSU. Nukus: 2015. -3839.

29. Ozhegov S.I. Explanatory Dictionary of the Russian Language / S.I.Ozhegov, Shvedova N.Yu. M .: Azbukovnik, 2003 .-- 653 p.

30. Pass Christopher. Dictionary of Economics Collins / C. Pass, B. Lowes, L. Davis - St. Petersburg: School of Economics, 2004, p. 489.

31. Sevruk V.T. Banking risks. - M .: Business, 1995, 72 p.

32. Tashmurodova B., Khamdamov O. Financial Management. Tutorial. Ministry of Higher and Secondary Special Education of the Republic of Uzbekistan, TMI, - T .: "Economy-Finance" 2012. 62 p.

33. Tursunov Sh.A. Financial Management. Tutorial. Tashkent, 2007. p.

34. Explanatory dictionary of the Uzbek language. State Scientific Publishing House "National Encyclopedia of Uzbekistan". Tashkent. Page 389.

35. Usoskin V.M. Risk management. M .: Finance and statistics, 2006. -s. 146 